\title{
Regression Analysis of Orthogonal, Cylindrical and Multivariable Color Parameters for Colorimetric Surface pH Measurement of Materials
}

\author{
Katarína Vizárová ${ }^{1, *(\mathbb{D})}$, Izabela Vajová ${ }^{1}$, Nad'a Krivoňáková ${ }^{2}$, Radko Tiňo ${ }^{1} \mathbb{D}$, Zdenko Takáč ${ }^{2} \mathbb{D}$, Štefan Vodný $^{3}$ \\ and Svetozár Katuščák ${ }^{1}$
}

check for

updates

Citation: Vizárová, K.; Vajová, I.; Krivoňáková, N.; Tiňo, R.; Takáč, Z.; Vodný, Š.; Katuščák, S. Regression Analysis of Orthogonal, Cylindrical and Multivariable Color Parameters for Colorimetric Surface $\mathrm{pH}$ Measurement of Materials. Molecules 2021, 26, 3682. https://doi.org/ $10.3390 /$ molecules 26123682

Academic Editor: Eulogio

J. Llorent-Martínez

Received: 26 April 2021

Accepted: 9 June 2021

Published: 16 June 2021

Publisher's Note: MDPI stays neutral with regard to jurisdictional claims in published maps and institutional affiliations.

Copyright: (c) 2021 by the authors. Licensee MDPI, Basel, Switzerland. This article is an open access article distributed under the terms and conditions of the Creative Commons Attribution (CC BY) license (https:/ / creativecommons.org/licenses/by/ $4.0 /)$.
1 Department of Wood, Pulp and Paper, Institute of Natural and Synthetic Polymers, Faculty of Chemical and Food Technology, Slovak University of Technology in Bratislava, Radlinského 9, 81237 Bratislava, Slovakia; izabela.vajova@stuba.sk (I.V.); radko.tino@stuba.sk (R.T.); svetozar.katuscak@stuba.sk (S.K.)

2 Institute of Information Engineering, Automation, and Mathematics, Faculty of Chemical and Food Technology, Slovak University of Technology in Bratislava, Radlinského 9, 81237 Bratislava, Slovakia; nada.krivonakova@stuba.sk (N.K.); zdenko.takac@stuba.sk (Z.T.)

3 Certex a.s., Radlinského 9, 81237 Bratislava, Slovakia; stefan.vodny@gmail.com

* Correspondence: katarina.vizarova@stuba.sk; Tel.: +421-917-669-018

\begin{abstract}
The surface $\mathrm{pH}$ is a critical factor in the quality and longevity of materials and products. Traditional fast colorimetric $\mathrm{pH}$ detection-based tests such as water quality control or pregnancy tests, when results are determined by the naked eye, cannot provide quantitative values. Using standard $\mathrm{pH}$ papers, paper-printed comparison charts, or colorimetric microfluidic paper-based analytical devices is not suitable for such technological applications and quality management systems (QMSs) where the particular tested material should contain a suitable indicator in situ, in its structure, either before or after the process, the technology or the apparatus that are being tested. This paper describes a method based on the combination of impregnation of a tested material with a $\mathrm{pH}$ indicator in situ, its exposure to a process of technology whose impact on $\mathrm{pH}$ value is to be tested, colorimetric $\mathrm{pH}$ measurement, and approximation of $\mathrm{pH}$ value using derived $\mathrm{pH}$ characteristic parameters $(\mathrm{pH}-$ CPs) based on CIE orthogonal and cylindrical color variables. The hypotheses were experimentally verified using the methyl red $\mathrm{pH}$ indicator, impregnating the acid lignin-containing paper, and preparing a calibration sample set with $\mathrm{pH}$ in the range 4 to 12 using controlled alkalization. Based on the performed measurements and statistical evaluation, it can be concluded that the best $\mathrm{pH}-\mathrm{CPs}$ with the highest regression parameters for $\mathrm{pH}$ are $\sqrt{ } \Delta E, \ln (a), \sqrt{ } \Delta H(a b), a / L, h / b$ and $\ln (b / a)$. The experimental results show that the presented method allows a good estimation of $\mathrm{pH}$ detection of the material surfaces.
\end{abstract}

Keywords: $\mathrm{pH}$ measurement; colorimetric $\mathrm{pH}$-metry; acidity; acid paper; deacidification

\section{Introduction}

The $\mathrm{pH}$ value has a significant impact on the quality and longevity of industrial and cultural heritage materials and objects, paper and packaging materials, forest products, construction materials and others. Therefore, $\mathrm{pH}$ is an important measured parameter in many areas, such as materials science and product manufacturing, storage, utilization, degradation, neutralization, mass deacidification, recycling, and evaluation of efficacy and quality of the related devices and technologies. It is also important for testing and quality management systems (QMSs).

When measuring the surface $\mathrm{pH}$ of porous materials [1] using $\mathrm{pH}$ meters or extraction methods [2-5], false results can be produced by redistribution of ions in the material structure caused by the application of water used for measurements or extraction. Examples of such false artifacts caused by improper measurement methods are given by several sources $[6,7]$. 
These problems can be mitigated by colorimetric $\mathrm{pH}$ measurement using suitable $\mathrm{pH}$ color indicators impregnated in situ into the measured porous material.

Color and other optical properties, namely those compatible with human vision, including the CIELab color space (three-dimensional color space defined by the International Commission on Illumination (abbreviated CIE)) variables, play an important role in many fields of rapid, low cost and human-like quality evaluation and decision-making, in terms of appearance, environmental quality, habitability, biocompatibility, natural character of materials and longevity assessment, including visual $\mathrm{pH}$ evaluation and colorimetric $\mathrm{pH}$ measurement [8]. A good example is fiber impregnation with color indicators and their colorimetric measurement for the automatization of objective identification of kinds of fibers $[9,10]$.

The $\mathrm{pH}$ indicators incorporated in situ into a fibrous material can be widely used in various applications, like monitoring of food freshness and quality [11], wound dressings able indicate the evolution of the healing process, protective clothing, filtration, etc. [12-14].

Measuring the change in $\mathrm{pH}$ using color indicators can be used to assess the biological degradation of materials using a biodegradation-specific $\mathrm{pH}$ indicator [15], such as $\mathrm{pH}$ measurement of the biological damage of test samples. Good examples are spruce wood chips used in pulp and paper, and wood logs in the woodworking and furniture industries stained with the $\mathrm{pH}$-indicator bromophenol [16,17].

To control the effectiveness of paper deacidification, Strlič [18] described a colorimetric method to quantify changes in reflectance spectra to determine the $\mathrm{pH}$ values of model samples. Boone used a $\mathrm{pH}$ indicator to impregnate a paper sample before deacidification to observe the neutralization effect after treatment [19]. Objective measurement of the 3D distribution of $\mathrm{pH}$ across a material's structure was designed and tested to evaluate the efficacy of porous material deacidification $[7,20]$.

This paper focuses on objective colorimetric $\mathrm{pH}$ measurement, based on a combination of impregnation of a tested material with a $\mathrm{pH}$ indicator in situ and its exposure to a tested process of technology, colorimetric measurement and data processing. Subsequently, based on regression analysis of CIE orthogonal and cylindrical color variables and derived $\mathrm{pH}$ characteristic parameters ( $\mathrm{pH}-\mathrm{CPs})$, the best $\mathrm{pH}-\mathrm{CPs}$ are selected. The CIE $1976(L, a, b)$ (CIELab) color system was used in this paper. The orthogonal $L a b$ and/or cylindrical chroma $C$ and hue $h$ parameters of the CIELab allow for a visualization of the $\mathrm{pH}$ and $\mathrm{pH}$-related properties, their distribution and kinetics in the orthogonal system of the 3 axes $L$ (lightness), $a$ (redness-greenness), $b$ (yellowness-blueness).

The colorimetric $\mathrm{pH}$ measurement can be used to measure the geometrical outer surfaces' $\mathrm{pH}$. This information is important for an assessment of materials' quality and longevity [6,21,22]; quality testing and management systems of materials [23], biomaterials, natural polymer materials and products such as cellulose, wood, paper [24-30] and building materials [31]; as well as in medical applications, such as the testing of skin [32-34].

A similar application of the new $\mathrm{pH}$-characteristic CIELab properties ( $\mathrm{pH}-\mathrm{CPs}$ ) can be used in automatization, quality management systems, feedback and feedforward control of modification and production processes of materials.

\section{Results}

This paper describes a rapid, low-cost colorimetric $\mathrm{pH}$ and $\mathrm{pH}$ distribution measurement of materials. The method using prestained samples can be used in such technological applications and QMSs where Whatman $\mathrm{pH}$ indicator paper, paper-printed comparison charts and colorimetric microfluidic paper-based analytical devices are not applicable.

The method consists of the following steps:

1. impregnation of a tested material with $\mathrm{pH}$ indicator in situ;

2. its exposure to a tested process of technology;

3. colorimetric $\mathrm{pH}$ measurement;

4. generation of new candidate $\mathrm{pH}$ characteristic parameters and selection of the best $\mathrm{pH}-\mathrm{CPs}$. 
An experimental verification of the hypotheses was made using a $\mathrm{pH}$ indicator impregnating a model material, in our case acid wood paper, using methyl red (MR) as the model $\mathrm{pH}$ indicator. The water deacidification process, used in archival document conservation, was chosen as the tested technology. A calibration sample set with $\mathrm{pH}$ in the range 4 to 10 (as measured by a pH meter) was prepared (see Figure 1) and color data in the CIE 1976 Lab color space were obtained.

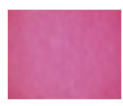

$\mathrm{pH}=4.2$

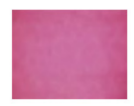

$\mathrm{pH}=5.2$



$\mathrm{pH}=5.6$

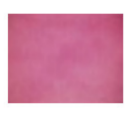

$\mathrm{pH}=6.0$

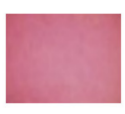

$\mathrm{pH}=7.0$



$\mathrm{pH}=7.9$

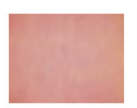

$\mathrm{pH}=8.4$

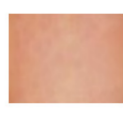

$\mathrm{pH}=9.0 \quad \mathrm{pH}=9.2$

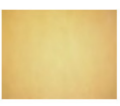

$\mathrm{pH}=9.8$

Figure 1. The calibration set of the $\mathrm{pH}$ indicator containing samples in the range $\mathrm{pH} 4-10$. Acidic papers were impregnated with the methyl-red solution and were alkalized by magnesium bicarbonate.

The first step in the analysis of measured data was a simple linear regression of all measured data-colorimetric parameters $L, a, b, C, h$, their ratios and differences, and the $\mathrm{pH}$ value. The most statistically significant results from the simple regression of orthogonal and cylindrical color variables and derived $\mathrm{pH}-\mathrm{CPs}$ according to the adjusted $\mathrm{R}$ squared values are given in Table 1.

Table 1. The best results for the simple linear regression between $\mathrm{pH}-\mathrm{CPs}$ and $\mathrm{pH}$.

\begin{tabular}{|c|c|c|}
\hline $\mathrm{pH}=12.0005-0.187229 \times a$ & $\mathrm{pH}=-16.3868+0.318285 \times L$ & $\mathrm{pH}=3.66558+0.0896278 \times h$ \\
\hline R2 (adjusted for d.f.) = 97.92\% & $\overline{\mathrm{R} 2}$ (adjusted for d.f.) $=97.81 \%$ & R2 (adjusted for d.f.) = 94.13\% \\
\hline $\mathrm{pH}=11.2954-11.3262 \times a / L$ & $\mathrm{pH}=-4.38203+6.21752 \times h / b$ & $\mathrm{pH}=9.83382-1.34982 \times a / b$ \\
\hline R2 (adjusted for d.f.) $=98.68 \%$ & R2 (adjusted for d.f.) $=98.03 \%$ & R2 (adjusted for d.f.) $=97.83 \%$ \\
\hline $\mathrm{pH}=4.27236-0.186781 \times \Delta a$ & $\mathrm{pH}=4.09775+0.319191 \times \Delta L$ & $\mathrm{pH}=5.03303+0.139455 \times \Delta H$ \\
\hline $\mathrm{R} 2$ (adjusted for d.f.) $=97.74 \%$ & $\mathrm{R} 2$ (adjusted for d.f.) $=97.63 \%$ & $\mathrm{R} 2$ (adjusted for d.f.) $=94.58 \%$ \\
\hline $\mathrm{pH}=4.35687+0.1365 \times \Delta E(1976)$ & $\mathrm{pH}=4.46478+0.183391 \times \Delta E(1994)$ & $\mathrm{pH}=4.5011+0.192817 \times \Delta E(C M C 1: 1)$ \\
\hline $\mathrm{R} 2$ (adjusted for d.f.) $=97.41 \%$ & $\mathrm{R} 2$ (adjusted for d.f.) $=96.75 \%$ & $\mathrm{R} 2$ (adjusted for d.f.) $=96.58 \%$ \\
\hline
\end{tabular}

d.f. - means the degrees of freedom. Adjusted $\mathrm{R}^{2}$ is a modified version of R-squared that has been adjusted for the number of predictors in the model.

The values of adjusted $\mathrm{R}$ squared given in Table 1 show that the best fitting models for $\mathrm{pH}$ prediction have been obtained with the following $\mathrm{pH}-\mathrm{CPs}$, in decreasing order of significance:

$$
a / L>h / b>a>a / b>L>\Delta a>\Delta L>\Delta E(1976)>\Delta E(1994)>\Delta E(\mathrm{CMC} 1: 1)>\Delta H>h
$$

where the highest value of adjusted $R^{2}$ is $98.68 \%(a / L)$.

In the next phase, the dependence of $\mathrm{pH}$ values on the colorimetric parameters $L, a, b$, $C, h$ was studied. To obtain the best fitting model using several parameters, the backward selection methods were applied.

The most statistically significant results from the regression of orthogonal and cylindrical parameters of $\mathrm{pH}-\mathrm{CP}$ according to the values of adjusted $\mathrm{R}$ squared can be seen in Table 2. 
Table 2. Determination of $\mathrm{pH}$ materials, statistically significant expressions. The values of adjusted $\mathrm{R}^{2}$ for relationships between candidate surface $\mathrm{pH}$ characteristic CIE color parameters (the tested orthogonal and cylindrical parameters, derived ratios, and total and partial color differences including both differences of hue $\Delta h_{a b}$ and $\Delta H_{a b}$ ) and the surface $\mathrm{pH}$ of material (model paper samples—-methyl red indicator containing acid paper with $\left.\mathrm{pH}_{0}=4.2\right) ; \operatorname{modified} \mathrm{using} \mathrm{Mg}\left(\mathrm{HCO}_{3}\right)_{2}$ solution gradually diluted $\mathrm{c} \mathrm{mol} / \mathrm{L}<0.0002,0.2>$; surface $\mathrm{pH}$ values of samples $<4.3,9.8>$ ).

\begin{tabular}{|c|c|c|c|c|}
\hline $\begin{array}{c}\text { Characteristic } \\
\text { Parameter; pH-CP }\end{array}$ & $\begin{array}{l}\text { Correlation } \\
\text { Coefficient; } \mathbf{r}\end{array}$ & $\mathbf{R}^{2} \%$ & $\mathbf{R}^{2}$ (Adjusted for d.f.) $\%$ & Equation \\
\hline \multicolumn{5}{|c|}{ Simple Regression } \\
\hline$\sqrt{ } \triangle E \mathrm{CMC}(1: 2)$ & 0.9958 & 99.15 & 99.11 & $\mathrm{pH}=2.98229+1.29486 \times \sqrt{ } \Delta E$ \\
\hline$\sqrt{ } \Delta E(2000)$ & 0.9956 & 99.13 & 99.08 & $\mathrm{pH}=\sqrt{ }(3.35706+16.7181 \times \sqrt{ } \Delta E)$ \\
\hline$\sqrt{ } \triangle E \mathrm{CMC}(1: 1)$ & 0.9954 & 99.08 & 99.03 & $\mathrm{pH}=2.83735+1.28324 \times \sqrt{ } \Delta E$ \\
\hline$\sqrt{ } \Delta E(1994)$ & 0.9951 & 99.02 & 98.97 & $\mathrm{pH}=2.76226+1.26054 \times \sqrt{ } \Delta E$ \\
\hline $\ln (a)$ & -0.9948 & 98.97 & 98.91 & $\mathrm{pH}=\sqrt{ }(162.231-38.3235 \times \ln (a))$ \\
\hline$\sqrt{ } \Delta E(1976)$ & 0.9945 & 98.90 & 98.84 & $\mathrm{pH}=2.57385+1.10343 \times \sqrt{ } \Delta E$ \\
\hline$\sqrt{ } \Delta H(a b)$ & 0.9942 & 98.84 & 98.78 & $\mathrm{pH}=4.39773+0.874399 \times \sqrt{ } \Delta H$ \\
\hline $\ln (b / a)$ & 0.9905 & 98.11 & 98.01 & $\mathrm{pH}=\sqrt{ }(64.3279+29.7346 \times \ln (b / a))$ \\
\hline$a$ & -0.9896 & 97.93 & 97.92 & $\mathrm{pH}=12.005-0.187229 \times a$ \\
\hline$\Delta E(1976)$ & 0.9877 & 97.55 & 97.41 & $\mathrm{pH}=4.35687+0.1365 \times \Delta E$ \\
\hline$\Delta E(1994)$ & 0.9845 & 96.92 & 96.75 & $\mathrm{pH}=4.46478+0.183391 \times \Delta E$ \\
\hline$\Delta E \mathrm{CMC}(1: 2)$ & 0.9826 & 96.55 & 96.36 & $\mathrm{pH}=4.56554+0.202441 \times \Delta E$ \\
\hline$\Delta b / \Delta a$ & -0.9802 & 96.08 & 95.86 & $\mathrm{pH}=(2.38378-0.920062 \times \Delta b / \Delta a)^{2}$ \\
\hline$\Delta b / \Delta a$ & 0.9794 & 95.92 & 95.70 & $\mathrm{pH}=5.78191-4.78967 \times \Delta b / \Delta a$ \\
\hline$\Delta H(a b)$ & 0.9754 & 95.14 & 94.87 & $\mathrm{pH}=\sqrt{ }(26.6656+1.3561 \times \Delta \mathrm{h})$ \\
\hline$\Delta H(a b)$ & 0.9740 & 94.86 & 94.58 & $\mathrm{pH}=5.03303+0.139445 \times \Delta H^{\prime}$ \\
\hline$\Delta E(2000)$ & 0.9668 & 93.47 & 93.11 & $\mathrm{pH}=4.82897+0.185748 \times \Delta E$ \\
\hline$\Delta H$ & 0.9570 & 91.58 & 91.12 & $\mathrm{pH}=5.15388+0.0948435 \times \Delta h$ \\
\hline$\Delta C$ & 0.9192 & 84.49 & 83.62 & $\mathrm{pH}=1 /(0.247154+0.0120777 \times \Delta C)$ \\
\hline$\Delta C$ & -0.8543 & 72.99 & 71.49 & $\mathrm{pH}=3.34293-0.482664 \times \Delta C$ \\
\hline \multicolumn{5}{|c|}{ Multiple Regression } \\
\hline$a, b, \Delta E, b / a, L / b$ & & 99.52 & 99.35 & $\begin{array}{c}\mathrm{pH}=13.9907-0.564697 \times a+0.689466 \times b- \\
0.923511 \times \Delta E+1.41696 \times b / a+0.948398 \times L / b\end{array}$ \\
\hline$H / L, H / C, C / L$ & & 99.49 & 99.39 & $\begin{aligned} \mathrm{pH}=10.3343+ & 22.3283 \times h / L-6.80628 \times \mathrm{h} / \mathrm{C} \\
& -13.4651 \times C / L\end{aligned}$ \\
\hline$\Delta H, \Delta H(a b), \Delta C$ & & 99.17 & 99.01 & $\begin{array}{c}\mathrm{pH}=4.26073+0.165637 \times \Delta H-0.0378499 \times \Delta h \\
-0.152348 \times \Delta C\end{array}$ \\
\hline$L, C, H$ & & 99.06 & 98.88 & $\begin{aligned} \mathrm{pH}=16.5441-0.00774926 & \times L-0.199133 \times C+ \\
0.0860289 & \times h\end{aligned}$ \\
\hline $\mathrm{C}, \mathrm{H}$ & & 99.03 & 98.91 & $\mathrm{pH}=10.5355-0.171271 \times C+0.0678806 \times h$ \\
\hline$a, L / a$ & & 99.01 & 98.90 & $\mathrm{pH}=14.5622-0.242712 \times a-0.302836 \times L / a$ \\
\hline$\sqrt{ } \Delta H, \Delta H$ & & 98.87 & 98.66 & $\begin{array}{c}\mathrm{pH}=1.40643+0.921009 \times \sqrt{ } \Delta H+\sqrt{ }(8.74598+ \\
-0.0307949 \times \Delta h)\end{array}$ \\
\hline$b / a, \Delta E(1976)$ & & 98.98 & 98.86 & $\mathrm{pH}=4.25415-0.747491 \times b / a+0.182809 \times \Delta E$ \\
\hline$\Delta b / \Delta a, \Delta H$ & & 98.07 & 97.84 & $\begin{array}{c}\mathrm{pH}=5.40496-2.70015 \times \Delta b / \Delta a+0.0646712 \times \\
\Delta H\end{array}$ \\
\hline$L, a, b$ & & 97.86 & 97.46 & $\begin{array}{c}\mathrm{pH}=13.4012-0.014403 \times L-0.197729 \times a- \\
0.0031366 \times b\end{array}$ \\
\hline
\end{tabular}

Based on the regression analysis, the order of the most significant color parameters dependent on $\mathrm{pH}$ according to the values of adjusted $\mathrm{R}$ squared is as follows:

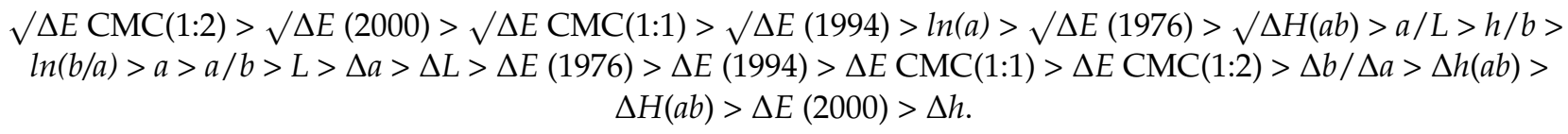

The analysis of multiple regression shows that the combinations of all selected variables (listed in Table 2) have the highest value of adjusted $\mathrm{R}^{2}$. However, the backward selection of variables shows only minor effects of variables other than $a$. Therefore, in this case, the most significant $\mathrm{pH}-\mathrm{CP}$ variable is $a$.

An example is given for the process analysis of the dependent variable $\mathrm{pH}$ and independent variables $L, a, b$; see Equations (1) and (2):

$$
p H=13.4012-0.014403 \times L-0.197729 \times a-0.0031366 \times b
$$




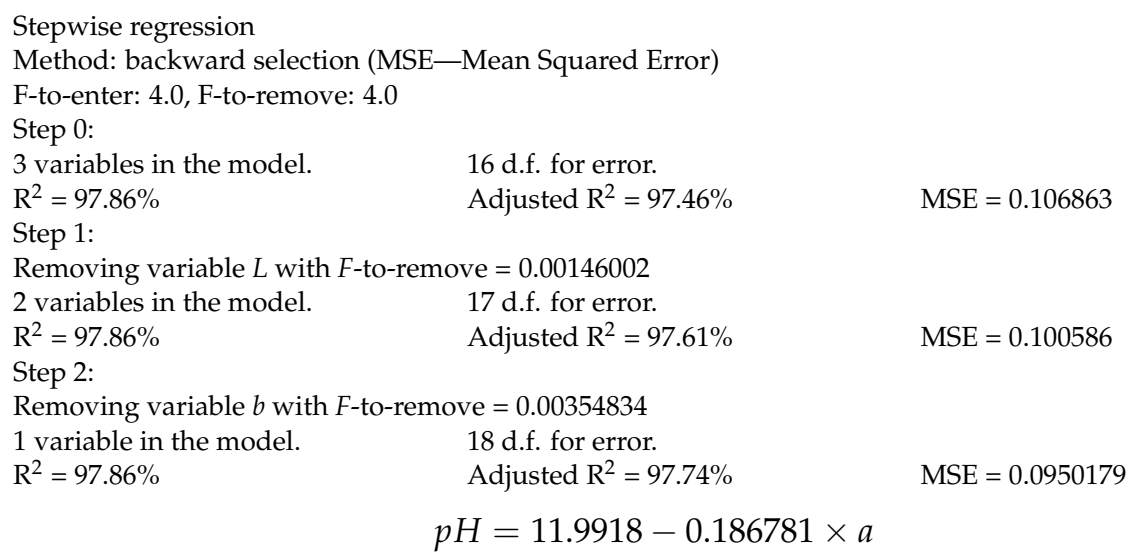

\section{Discussion}

The regression shows a strong dependence between all types of total color difference and the $\mathrm{pH}$ value. In this case, it is not important which formula for the total color difference is used. In all cases, $\Delta E$ is the total color difference for the orthogonal parameters $L, a, b$, between the measured sample and the reference, with the most acidic paper standard site used with $\mathrm{pH}=4.2 ; L_{r e f}=64.4, a_{r e f}=41.3, b_{r e f}=10.8$.

$\Delta H_{a b}$ and $\Delta h_{a b}$ are differences in cylindrical parameters $L, C, H_{a b}$ between the measured sample and the reference, with the most acidic paper standard site used with $\mathrm{pH}=4.2$; $L_{r e f}=64.4, C_{r e f}=42.7, H_{a b r e f}=14.5^{\circ}$.

The reason for this is the fact that during the transition from the acidic to the alkaline environment, there is a transition from red to yellow and within this transition, there is a shift to lower values of the coordinate $a$ as well as an increase in the value of $b$, and there is also a small difference in $L$ values.

Multiple regression analyses carried out reveal the major influence of the value of orthogonal coordinates $a, b$ and cylindrical coordinates $C, H_{a b}$. The best $\mathrm{pH}$-CPs with the highest correlation parameters with $\mathrm{pH}$ are listed in Table 3.

Table 3. The most significant relationships between $\mathrm{pH}$ and orthogonal (a) and cylindrical (b) CIELAB parameters according to the adjusted $\mathrm{R}^{2}$ values.

\begin{tabular}{cc} 
(a) & (b) \\
\hline$L, a, b$ & $L, C, h$ \\
$\mathrm{pH}=\sqrt{ }(162.231-38.3235 \times L n(a))$ & $\mathrm{pH}=10.3343+22.3283 \times h / L-6.80628 \times h / C-13.4651 \times$ \\
$\mathrm{R}^{2}=98.91 \%$ & $C / L$ \\
$\mathrm{pH}=14.5622-0.242712 \times a-0.302836 \times L / a$ & $\mathrm{R}=99.39 \%$ \\
$\mathrm{R}^{2}=98.90 \%$ & $\mathrm{pH}=16.5441-0.00774926 \times L-0.199133 \times C+0.0860289 \times h$ \\
$\mathrm{pH}=11.2954-11.3262 \times a / L$ & $\mathrm{RH}=10.5355-0.171271 \times C+0.0678806 \times h$ \\
$\mathrm{R}^{2}=98.68 \%$ & $\mathrm{R}^{2}=98.91 \%$ \\
\hline
\end{tabular}

\section{Materials and Methods}

\subsection{Materials}

Test acid lignin-containing paper was used from Klug-Conservation (Immenstadt im Allgäu, Germany). Methyl red (MR) was purchased from Sigma-Aldrich (Darmstadt, Germany). Magnesium hydroxide was supplied by Sigma-Aldrich.

\subsection{Methods}

\subsubsection{Sample Preparation}

The indicator was dissolved ( $1 \mathrm{~g} / \mathrm{L} \mathrm{MR}$ ethanol:water/2:1). Test paper was cut to size $5 \times 5 \mathrm{~cm}$. The samples were immersed in indicator solution for $1 \mathrm{~min}$. After dyeing, all samples were dried under laboratory conditions. 
The alkali solution of magnesium bicarbonate was prepared by adding $12 \mathrm{~g} / \mathrm{L}$ of magnesium hydroxide into a pressure reactor and mixing under a pressure of $5 \mathrm{~atm}$ for $2 \mathrm{~h}$ in a $\mathrm{CO}_{2}$ atmosphere. The set of fresh calibration solutions was prepared from 0.2 to $0.0002 \mathrm{~mol} / \mathrm{L}$ (temperature conditions $4{ }^{\circ} \mathrm{C}$ ).

The calibration samples were prepared by immersing the dyed samples into alkali solutions for $1 \mathrm{~min}$. Subsequently, the samples were air-dried under laboratory conditions. The homogeneity of indicator staining, as well as the homogeneity of neutralization, were observed in the cross-section of the samples by optical microscopy (transverse and longitudinal section of the paper, Figure 2).

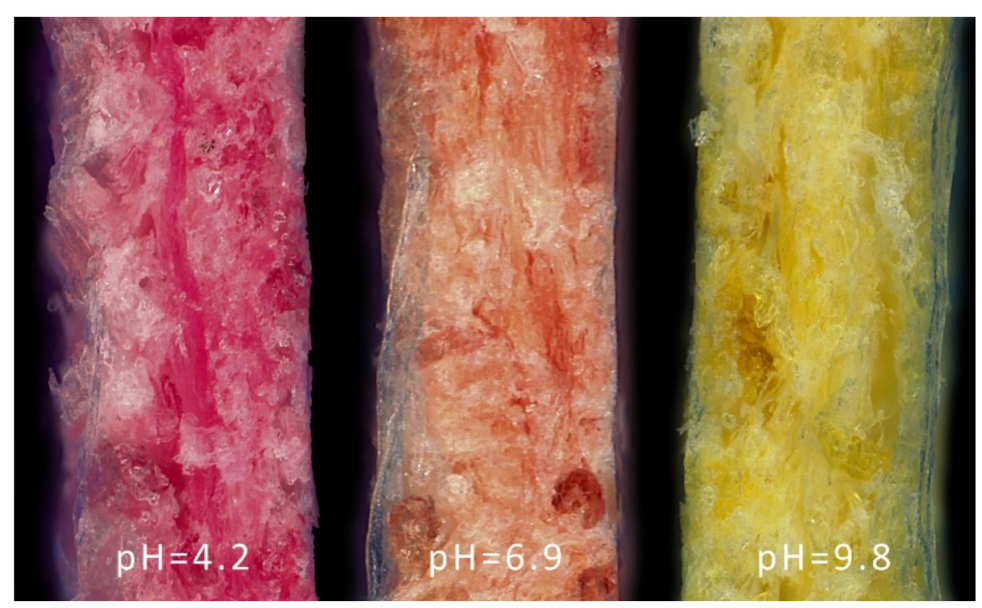

Figure 2. Cross-section of the calibration paper samples.

\subsection{2. $\mathrm{pH}$ Measurement}

The $\mathrm{pH}$ meter Jenway 3510 (Bibby Scientific Ltd, Staffordshire, UK) was used. Surface $\mathrm{pH}$ measurements were executed with a flat-surface combined $\mathrm{pH}$ electrode (Mettler TOLEDO, Columbus, OH, USA). According to the Tappi 529 [1] standard method, a drop of water $(50 \mu \mathrm{L})$ was placed on a sample, the flat-surface combined $\mathrm{pH}$ electrode pressed against it, and the $\mathrm{pH}$ value read after being constant for $30 \mathrm{~s}$. The results are an average of 10 determinations.

\subsubsection{Color Parameter Measurement}

The coordinates were measured with a Spectro-Densitometer (SpectroDens, Techkon, $\mathrm{GmbH}$, Königstein, Germany) by CIE-Lab using a D50/2 ${ }^{\circ}$ illuminant without polarization, according to the Tappi $524 \mathrm{om}-94$ [35]. The samples were measured on 5 different spots on both sides. The average value of the measurement was calculated from two parallels. $L, C$, $h$ coordinates were calculated from $L, a, b$ coordinates (Equations (3) and (4)):

$$
\begin{aligned}
C_{a b} & =\sqrt{a^{2}+b^{2}} \\
h_{a b} & =\tan ^{-1}\left(\frac{b}{a}\right)
\end{aligned}
$$

$L$ represents lightness, $a$ is approximate redness-greenness, $b$ is approximate yellownessblueness, $C_{a b}$ is chroma, and $h_{a b}$ is hue. The $L, a$ and $b$ coordinates are used to construct a Cartesian color space. The $L, C_{a b}$, and $h_{a b}$ coordinates are the cylindrical representation of the same space.

Color differences are measured in the CIELab space as the Euclidean distance between the coordinates for the two stimuli. This is expressed in terms of a CIELab $\Delta E_{a b}$, which can be calculated using Equation (5):

$$
\Delta E_{a b}=\sqrt{\Delta L^{2}+\Delta a^{2}+\Delta b^{2}}
$$


The differences between the reference sample (the most acidic sample) and the sample from the calibration set were compared. The magnitude of the color difference was quantified by $\Delta E_{a b}$, with $\Delta L$ the lightness difference, and $\Delta a$ and $\Delta b$ the difference in $a$ and $b$ values.

It can also be expressed in terms of lightness, chroma $\left(\Delta C_{a b}\right)$, and hue $\left(\Delta H_{a b}\right)$ differences as illustrated in Equations (6) and (7):

$$
\begin{aligned}
& \Delta E_{a b}=\sqrt{\Delta L^{2}+\Delta C_{a b}^{2}+\Delta H_{a b}^{2}} \\
& \Delta H_{a b}=\sqrt{\Delta E_{a b}-\Delta L^{2}-\Delta C_{a b}^{2}}
\end{aligned}
$$

While the CIELab color space was designed to have color differences perceptually uniform throughout the space, this goal was not strictly achieved.

To improve the uniformity of color difference measurements, modifications to the CIELab $\Delta E_{a b}$ equation have been made based upon various empirical data. One of the most widely used modifications is the CMC color difference equation [36], which is based on a visual experiment on color difference perception in textiles. The CIE (1995b) has recently evaluated such equations and the available visual data, recommending a new color difference equation for industrial use. This system for color difference measurement is called the CIE $1994\left(\Delta L, \Delta C_{a b}, \Delta H_{a b}\right)$ color difference model.

The last difference that the CIE established was the CIE DE2000 color difference equation [37] that extends the concept of CIE94 with further complexity.

While the statistical validity of the DE2000 computations for most real-world applications is questionable, the equation is gaining in popularity and most certainly represents an improvement over the simple CIELab color difference equation for almost any application [38].

Statistical data processing was performed by methods of regression analysis. The results of fitting several curvilinear models to the data were found and compared by the $\mathrm{R}^{2}$ values. Since the models with an unequal number of parameters were compared, to obtain a significant comparison, the values of $\mathrm{R}$ squared were adjusted. All measured data were processed in the program Statgraphics Centurion XV, Version 15.2.05.

\section{Conclusions}

The key idea and aim of this work was to generate and test candidate $\mathrm{pH}$ characteristic parameters for a quick, low-cost, rapid measurement of $\mathrm{pH}$. The procedure used consists of impregnation of a tested material with $\mathrm{pH}$ indicator in situ, further of its exposure to a tested process of technology (colorimetric $\mathrm{pH}$ measurement) then of correlation analysis of $\mathrm{CIE}$ orthogonal and cylindrical color variables and derived $\mathrm{pH}$ characteristic parameters $(\mathrm{pH}-\mathrm{CP})$, and finally of selecting the best $\mathrm{pH}-\mathrm{CP}$.

A simple linear regression of all measured data was performed. The most statistically significant results among orthogonal and cylindrical color variables and derived $\mathrm{pH}-\mathrm{CP}$ variables according to the adjusted $\mathrm{R}^{2}$ were $a / \mathrm{L}(98.68 \%), h / b(98.03 \%), a(97.92 \%)$ and $a / b$ (97.83\%).

The color CIE parameters, obtained by regression of orthogonal and cylindrical parameters of $\mathrm{pH}-\mathrm{CPs}$ according to the values of adjusted $\mathrm{R}^{2}$, best correlating with $\mathrm{pH}$, and therefore the most suitable for measurement of $\mathrm{pH}$ of used materials, are as follows: $\sqrt{ } \triangle E \mathrm{CMC}(1: 2), \sqrt{ } \Delta E(2000), \sqrt{ } \Delta E \mathrm{CMC}(1: 1), \sqrt{ } \Delta E(1994)(99.11 \%-98.97 \%), \ln (a)(98.91 \%)$, $\sqrt{ } \Delta E(1976)(98.84 \%), \sqrt{ } \Delta H(\mathrm{ab})(98.78 \%), a / L(98.68 \%), h / b(98.03 \%)$ and $\ln (b / a)(98.01 \%)$. The backward selection of variables shows that, in this case, the most significant $\mathrm{pH}-\mathrm{CP}$ variable and thus the most characteristic value for $\mathrm{pH}$ determination in the case of the paper substrate is the coordinate $a$.

The experimental results obtained using the $\mathrm{pH}$-indicator impregnation in combination with the best $\mathrm{pH}-\mathrm{CP}$ show that it allows for a good estimation of $\mathrm{pH}$ values of the external surfaces. Superior and easy $\mathrm{pH}$ estimation is achieved using colorimetric 
$\mathrm{pH}-\mathrm{CP}=\sqrt{ } \Delta E$ measurement in the application simply using surface CIELab color data for the material impregnated with color $\mathrm{pH}$ indicator. The application of the above-mentioned method seems to be promising for the evaluation of $\mathrm{pH}$ values of paper microstructures [7].

\section{Patents}

Katuščák, S., Vodný, Š., Vizárová, K.: pH Distribution measurement in a porous material microstructure. Method and apparatus. PCT/IB2018/053927, WO/2019/229504 (2019).

Author Contributions: Conceptualization and methodology, K.V., S.K. and Š.V.; formal analysis, data curation, N.K., I.V. and Z.T.; investigation, I.V., R.T.; writing —original draft preparation, K.V. and S.K.; writing - review and editing, I.V. and R.T.; supervision, K.V. All authors have read and agreed to the published version of the manuscript.

Funding: This research was funded by the Slovak Agency for Research and Development (APVV) (Project 18-0155 MUFUSCEM).

Institutional Review Board Statement: Not applicable.

Informed Consent Statement: Not applicable.

Data Availability Statement: The data presented in this study are available on request from the corresponding author. The data are not publicly available due to the fact that research is still in progress.

Conflicts of Interest: The authors declare no conflict of interest. The funders had no role in the design of the study; in the collection, analyses, or interpretation of data; in the writing of the manuscript, or in the decision to publish the results.

Sample Availability: Samples of the test papers are available from the authors upon request.

\section{References}

1. TAPPI. Surface pH Measurement; Technical Association of the Pulp and Paper Industry, 15 Technology Parkway South, Suite 115, Peachtree Corners, GA 30092 United States, 529 om-14. 2004. Available online: https:/ /imisrise.tappi.org/TAPPI/Products/01 /T/0104T529.aspx (accessed on 5 June 2021).

2. TAPPI. Hydrogen Ion Concentration (pH) of Paper Extracts (Cold Extraction Method); Technical Association of the Pulp and Paper Industry, 15 Technology Parkway South, Suite 115, Peachtree Corners, GA 30092 United States, 509 om-02. 2006. Available online: https:/ /imisrise.tappi.org/TAPPI/Products/01/T/0104T509.aspx (accessed on 5 June 2021).

3. TAPPI. Hydrogen Ion Concentration $(\mathrm{pH})$ of Paper Extracts (Hot Extraction Method); Technical Association of the Pulp and Paper Industry, 15 Technology Parkway South, Suite 115, Peachtree Corners, GA 30092 United States, 435 om-02. 2006. Available online: https:/ / www.tappi.org/content/SARG/T435.pdf (accessed on 5 June 2021).

4. ISO 6588-1, Paper, Board, and Pulps. In Determination of pH of Aqueous Extracts Part 1. Cold Extraction. 2005. Available online: https:/ / www.iso.org/standard/59783.html (accessed on 5 June 2021).

5. ISO 6588-2, Paper, Board, and Pulps. Determination of pH of Aqueous Extracts. Part 2. Hot Extraction. 2005. Available online: https:/ / www.iso.org/obp/ui/\#iso:std:iso:6588:-2:ed-1:v1:en (accessed on 5 June 2021).

6. Hubbe, M.A.; Smith, R.D.; Zou, X.; Katuscak, S.; Potthast, A.; Ahn, K. Deacidification of acidic books and paper by means of non-aqueous dispersions of alkaline particles: A review focusing on the completeness of the reaction. BioResources 2017, 12, 4410-4477. [CrossRef]

7. Vajová, I.; Vizárová, K.; Tiňo, R.; Krivoňáková, N.; Takáč, Z.; Katuščák, S. Monitoring of pH distribution through pH related properties in deacidified model paper. Eur. Phys. J. Plus 2021, 136, 578. [CrossRef]

8. Gfeller, B.; Katuščák, S.; Höllmüller, C. Zu den Wechselwirkungen zwischen Organismen und den in der Umwelt Eingesetzten Materialien. Holzforsch. Holzverw. 1994, 46, 25-28.

9. Jablonský, M.; Dubinyová, L.; Varga, Š.; Vizárová, K.; Šima, J.; Katuščák, K. Cellulose Fibre Identification through Color Vectors of Stained Fibre. BioResources 2015, 10, 5845-5862. [CrossRef]

10. Stevek, J.; Katuščák, S.; Dubinyová, L.; Fikar, M. An automatic identification of wood materials from color images. In Proceedings of the 28th International Conference 2016 Cybernetics \& Informatics (K\&I), Levoča, Slovakia, 2-5 February 2016.

11. Kalpana, S.; Priyadarshini, S.R.; Leena, M.M.; Moses, J.A.; Anandharamakrishnan, C. Intelligent packaging: Trends and applications in food systems. Trends Food Sci. Tech. 2019, 93, 145-157. [CrossRef]

12. Van der Schueren, L.; De Clerck, K. The use of $\mathrm{pH}$-indicator dyes for $\mathrm{pH}$-sensitive textile materials. Text. Res. J. 2010, 80, 590-603. [CrossRef]

13. Van de Schueren, L.; De Clerck, K. Coloration and application of pH-sensitive dyes on textile materials. Color. Technol. 2012, 128, 82-90. [CrossRef] 
14. Van der Schueren, L.; De Clerck, K.; Brancatelli, G.; Rosace, G.; Van Damme, E.; De Vos, W. Novel cellulose and polyamide halochromic textile sensors based on the encapsulation of Methyl Red into a sol-gel matrix. Sens. Actuator B Chem. 2012, 162, 27-34. [CrossRef]

15. Willeitner, H. Possibilities, and problems related to the incorporation of fungicides and insecticides into primers and lacquers used for the treatment of wood. Fette Seifen Anstr. 1974, 76, 533-538. [CrossRef]

16. Katuščáková, G.; Katuščák, S. Identification of the Biologically Damaged Spruce Wood Chips for the Delignification Process (Identifikácia a delignifikácia biologicky poškodených smrekových štiepok). Papir a Celuloza 1986, 41, V41-V44.

17. Katuščák, S.; Katuščáková, G. Means of Objective Identification of Spruce Wood Decay. Holzforschung 1987, 41, 315-320. [CrossRef]

18. Strlic, M.; Kolar, J.; Kocar, D.; Drnovsek, T.; Selih, V.S.; Susic, R.; Pihlar, B. What is the pH of alkaline paper? E Preserv. Sci. 2004, 1, 35-47.

19. Boone, T.; Russick, S.; Kidder, L. Bookkeeper®for Spray Use in Single Item Treatments; Book and Paper Group Annual; Book and Paper Group: 1998; Volume 17. Available online: https://cool.culturalheritage.org/coolaic/sg/bpg/annual/v17/bpga17-04.pdf (accessed on 5 June 2021).

20. Katuščák, S.; Vodný, S.; Vizárová, K. pH Distribution measurement in a porous material microstructure. Method and apparatus. PCT/IB2018/053927, WO/2019/229504 (2019).

21. Allscher, T.; Ceynowa, I. Mengenentsäuerung-Verfahrensvalidierung, Evaluierung und Qualitätssicherung. Neue Einsichten und bleibende Fragen. ABI Technik. 2018, 38, 16-28. [CrossRef]

22. Hubbe, M.A.; Henniges, U.; Potthast, A.; Ahn, K.; Smith, R.D. Nonaqueous Solution Deacidification Treatments to Prolong the Storage Life of Acidic Books: A Review of Mechanistic and Process Aspects. BioResources 2018, 13, 7096-7136. [CrossRef]

23. Hackney, S. Colour measurement of acid-detector strips for the quantification of volatile organic acids in storage conditions. Stud. Conserv. 2016, 61, 55-69. [CrossRef]

24. Potthast, A.; Ahn, K. Critical evaluation of approaches toward mass deacidification of paper by dispersed particles. Cellulose 2017, 24, 323-332. [CrossRef]

25. Vizárová, K.; Kirschnerová, S.; Kačík, F.; Briškárová, A.; Šutý, Š.; Katuščák, S. Relationship between the decrease of degree of polymerization of cellulose and the loss of groundwood pulp paper mechanical properties during accelerated ageing. Chem. Pap. 2012, 66, 1124-1129. [CrossRef]

26. Katuščák, K.; Kučera, J.L.; Varga, Š.; Čeppan, M.; Šuty, Š.; Jablonský, M. New method of recognition of wood species. Increasing the effectiveness of colorimetric recognition of Picea excelsa and Abies alba. Wood Res. Slovak. 2012, 47, 1-12.

27. Jablonský, M.; Botková, M.; Hroboňová, K. Accelerated ageing of wood containing papers: Formation of weak acids and deterioration of tensile strength. Wood Res. Slovak. 2012, 57, 419-434.

28. Jablonský, M.; Hroboňová, K.; Katuščák, S.; Lehotay, J.; Botková, M. Formation of acetic and formic acid in unmodified and modified papers during accelarated ageing. Cell. Chem. Technol. 2012, 46, 331.

29. Hubbe, M.A. Finishing deacidification. BioResources 2015, 10, 6305-6309. [CrossRef]

30. Ahn, K. Sustainability of Mass Deacidification of Library Objects. Ph.D. Thesis, Universität für Bodenkultur, Wien, Austria, 2013.

31. Behnood, A.; Tittelboom, K.; De Belie, N. Methods for measuring pH in concrete: A review. Constr. Build. Mater. 2016, 105, 176-188. [CrossRef]

32. Plessis, J.L.; Stefaniak, A.B.; Wilhelm, K.P. Measurement of Skin Surface pH. In $p H$ of the Skin: Issues and Challenges; Current Problems in Dermatology; Surber, C., Abels, C., Maibach, H., Eds.; Karger: Basel, Switzerland, 2018; Volume 54, pp. 19-25.

33. Gethin, G. The significance of surface $\mathrm{pH}$ in chronic wounds. Wounds 2007, 3, 52.

34. Lambers, H.; Piessens, S.; Bloem, A.; Pronk, H.; Finkel, P. Natural skin surface pH is on average below 5, which is beneficial for its resident flora. It. J. Cosmet. Sci. 2006, 28, 359-370. [CrossRef]

35. TAPPI. Color of Paper and Paperboard $\left(45^{\circ} / 0^{\circ}\right)$; Technical Association of the Pulp and Paper Industry, 15 Technology Parkway South, Suite 115, Peachtree Corners, GA 30092 United States, 524 om-94. 1994. Available online: https:/ /www.complianceonline. com/images/supportpages/501032/sample_T524.pdf (accessed on 5 June 2021).

36. Clarke, F.J.J.; McDonald, R.; Rigg, B. Modification to the JPC 79 colour- difference formula. J. Soc. Dyers Colour. 1984, 100, 128-132 [CrossRef]

37. Johnson, G.M.; Fairchild, M.D. A top down description of S-CIELAB and CIEDE2000. Color. Res. Appl. 2003, 28, 425-435. [CrossRef]

38. Fairchild, M.D. Color Appearance Models; John Wiley \& Sons: Hoboken, NJ, USA, 2013. 